\title{
小児の脊髄血行障害による脊髄麻痺例の脊柱変形について
}

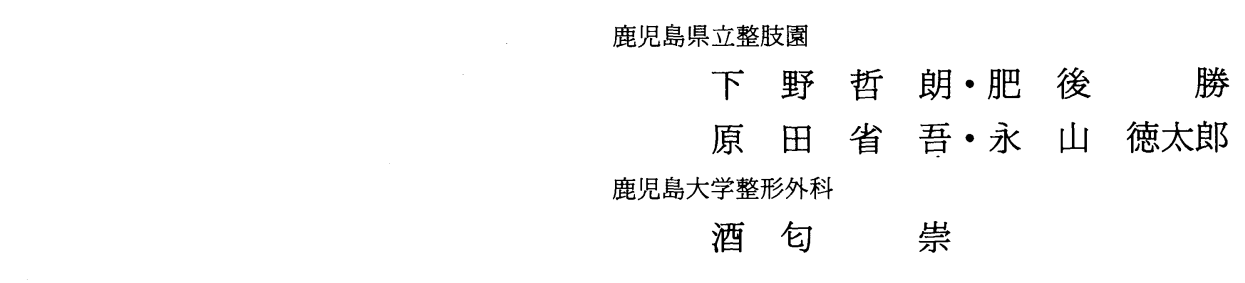

\section{Spinal Deformity Subsequent to Paraplegia due to Vascular Disorders of the Spinal Cord in Children}

\author{
by \\ Tetsuro Shimono, Masaru Higo \\ Shougo Harada and Tokutaro Nagayama \\ Kagoshima Crippled Children's Hospital \\ Takashi Sakou \\ Department of Orthopedic Surgery, \\ Faculty of Medicine, Kagoshima University
}

\begin{abstract}
Vascular dicorders of the spinal cord are rarely seen. We investigated the spinal deformity in four children who were suspected to have a vascular disorder of the spinal cord. They all were girls at the age of six to ten years when paralysis had developed, and turned out to be complete below the $\mathrm{T} 10$ or T11 level. The follow-up ranged from two to 17 years and severe scoliosis was found in two of them. Both cases were neglected in the treatment of the spinal deformity. From this fact, close attention should be given to a spinal deformity due to spinal palsy, especially in children below the age of ten years.
\end{abstract}

は じめに

春髄血行障害は比較的まれな疾患であり,その診断, 検査, 治療に関する報告は多いがそれに起因した麻盘 性脊柱変形についての報告はまれである。今回われわ れは，小児期に発症した泰䯣血行障害の疑いによる脊 髄麻痷で，脊柱変形を生じ自然に放置された 3 例と装 具治療中の 1 例を経験したのでその脊柱変形について 報告する。

症例

症例 $1: 10$ 才，女览。

倒立着地後, Th 10 以下の弛緩性完全麻痷が生じた。 胸腰椎単純 X線写真, ミエログラフィーでは, 異常所
見は認められなかった(表 1).以後も麻痷は持続した. 麻疸発症 2 年 9 力月後, 左凸 $17^{\circ}$ の胸腰椎側弯が生じ たが, 難治性褯創などのため自然経過例となった，麻 盘発症 17 年後, 26 才の調查時には座位で左凸 $38^{\circ}$ の胸 腰椎側弯 (Th9-L5), 胸椎後弯抢よび腰椎前弯の消失 を認めたが脊柱支持性は良好であった。また $12^{\circ}$ の骨盤 傾斜と両股関節の $30^{\circ}$ の屈曲拘縮，亚脱臼も認めた。 症例 $2: 8$ 才，女児.

運動による怒責を誘因として発症し, 約 10 分後に両 下肢はTh 10 以下の弛緩性完全麻痺となった。 発症 5 日後の髄液では, 外観はキサントクロミーを呈し, 細 胞数の増加, 多数の赤血球, 軽度の蛋白量の増加を認 めた。胸腰椎単純 $\mathrm{X}$ 線写真, ミエログラフィーおよび 脊䯣血管造影では, 明瞭な異常所見は認められなかっ 
表 1 麻痺発症時の検查所見

\begin{tabular}{|c|c|c|c|c|c|c|c|}
\hline 症例 & 外 観 & $\begin{array}{l}\text { 髄液所見 } \\
\text { 細胞数 }\end{array}$ & $\begin{array}{l}\text { 蛋 白 量 } \\
(\mathrm{mg} / \mathrm{dl})\end{array}$ & $\begin{array}{l}\text { 胸腰椎単純 } \\
\mathrm{X} \text { 線 写真 }\end{array}$ & ミ工口 & 脊髄血管造影 & MR I \\
\hline 1 & - & - & - & 異常なし & 異常なし & - & - \\
\hline 2 & Xanth. & $557 / 3 \mathrm{RBC}$ & 75 & 異常なし & 異常なし & 異常なし & - \\
\hline 3 & Xanth. & $97 / 3$ & 99 & 異常なし & $\begin{array}{l}\text { Th9.12 に } \\
\text { A VM? }\end{array}$ & $\begin{array}{c}\text { Th12-L1の } \\
\text { 前福髄動脈に } \\
\text { 屈 曲, 蛇 行 }\end{array}$ & - \\
\hline 4 & Xanth. & $276 / 3 \mathrm{RBC}$ & 64 & 異常なし & 異常なし & 異常なし & 異常なし \\
\hline
\end{tabular}

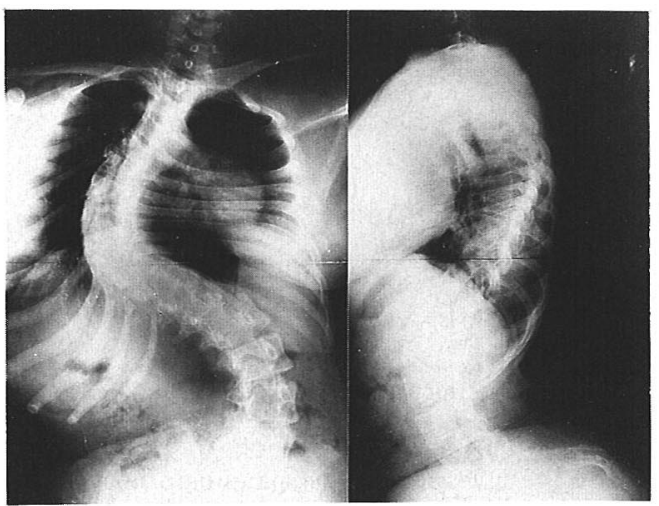

a

b

図 1 症例 $3: 16$ 才調查時の座位脊柱 $\mathrm{X}$ 線写真

a. 前後像 胸椎側弯 $79^{\circ}$ (Th2-L2)

b. 側面像 胸椎後弯 $58^{\circ}$ (Th2-Th12)

腰椎前弯 $72^{\circ}$ (L1-L5)

た（表 1 ). 以後も麻痺は持続した。

麻痺発症 6 力月後, 臥位で左凸 $35^{\circ}$ の胸椎側弯に気付 いたが, 難治性裖創などのため装具治療できなかった。 麻痺発症 4 年後には, 側弯は, 卧位で $62^{\circ}$ の腰椎側弯へ と短期間で高度に進行した。この時点で右股関節亜脱 臼も認めた。この後, 他医へ転医した。

症例 $3: 8$ 才，女児。

転倒 2 時間後に Th 11 以下の弛緩性完全麻痺となっ た。発症 5 日後の髄液では，外観はキサントクロミー を呈し, 細胞数の増加, 軽度の蛋白量の増加を認めた。 胸腰椎単純 $\mathrm{X}$ 線写真では異常所見は認められず, ミエ ログラフィーでは，Th 9-12 に動静脈奇形 (AVM) が 疑われる所見を得たが, 毟髄血管造影では, AVM は認 められず, Th12-L1 の前脊髄動脈に屈曲, 蛇行が認め られた (表 1 )。以後も麻痺は持続した。

麻痺発症 4 力月後の臥位レ線写真で右凸 $10^{\circ}$ の胸椎

側弯 (Th2-L1) を認めた。 以後, 治療を拒否し在宅で 車椅子生活するようになった。麻痺発症 8 年後, 16 才 の調査時では, 高度の右凸胸椎側弯, 胸椎後弯および 腰椎前弯の増強を認め，座位保持には上肢支持が必要 となっていた.また $10^{\circ}$ の骨盤傾斜と両股関節の $30^{\circ}$ の 屈曲拘縮, 右股関節亜脱臼も認めた。調查時の座位レ 線写真では, 右凸 $79^{\circ}$ の胸椎側弯と $58^{\circ}$ の胸椎後弯, $72^{\circ}$ の腰椎前弯を認める(図 1)。

症例 : 4,6 才，女児。

うさぎ跳びした 1 時間半後, 両下肢の疼痛, シビレ をきたし, 半日後には, 両下肢完全麻痺となり, 以後 Th 10 以下の弛緩性完全麻㽻となった。発症 5 日後の髄 液では, 外観はキサントクロミーを呈し, 細胞数の増 加, 多数の赤血球, 軽度の蛋白量の増加を認めた。胸 腰椎単純 X線写真, ミエログラフィー,ミエロ CT, 脊 髄血管造影, MRI では, 明瞭な異常所見は認められな かった（表 1).

麻痺発症 4 力月後, 臥位で右凸 $10^{\circ}$ の胸椎側弯, 座位 で $20^{\circ}$ と $24^{\circ}$ の胸椎・腰椎ダブルカーブ型側弯に気付き, アンダーアームブレース装着し, 治療開始した。麻痺 発症後 2 年の現在, 麻瘒は不変で, 両股関節の $30^{\circ}$ の届 曲拘縮があり, 脊柱変形に対しアンダーアームブレー ス装着治療中である。現在のレ線写真では, 右凸 $14^{\circ}$ の 胸椎側弯 (Th6-L2) と $79^{\circ}$ の胸腰椎前弯増強(Th8-L5) を認める。

\section{考察およびまとめ}

小児の春䯣損傷後の麻㾝性脊柱変形の出現頻度につ いて, Campbell と Bonett ${ }^{2)}$ は $91 \%$, Mayfield ら ${ }^{5)}$ $96 \%$, Kilfoyle ら ${ }^{3)}$ は $93 \%$ の高頻度に発生すると報告 しているが，成長期にある小児の脊骾血行障害も春髄 麻瘏をきたすとわれわれの症例のように麻痺性脊柱変 形の発生をみる。 
麻痺性脊柱変形の発現と進行に影響をおよぼす大き な要因として脊髄麻痺発症時の年令, 重力, 神経学的 障害の程度と高位, 痤性などが挙げられている(4)5). Brown ら ${ }^{1)}$ は, 成長期の小児の麻痺性脊柱変形の発現 について春髄損傷により急に骨性脊柱の麻瘏部以下の 筋性支持が失われ, 勒帯のみでは重力に抗して骨性脊 柱の支持と均整の維持ができず軽度の curve が生じ, さらに椎体終板への非対称性負荷や椎間板, 椎体, 椎 間関節の変形も加わり curve の進行をみるとし，さら に脊髄麻痺発症時, 年少なものほど脊柱変形が生じや すく，未治療例は高度脊柱変形になりやすいと述べて いる.われわれの症例は, いずれも 6 才から 10 才の成 長期に下位胸髄レベルに弛緩性完全麻痺を生じたもの であり， 2 例には麻痺発症 4 力月後に, 他の 1 例では 6 力月後に側弯が認められており, 早期より側弯が出 現するものと考える. 3 例の自然経過例中， 8 才時麻 痺発症した 2 例は高度脊柱変形に進行し, 10 才時麻瘏 発症例は 26 才の調查時, $38^{\circ}$ の中等度側弯であったが, 両者の差は麻舫発症時の年令差によるものと考える. 高度側弯となるか, 軽度側弯となるかは, Lancourt ら が述べているように 10 才が分岐点になろうかと考える. 諸家 ${ }^{1334)}$ によると骨盤傾斜や股関節拘縮, 覀脱臼, 脱
臼も脊柱変形の発生や進行に影響を及ぼすとされてお り，麻痺性側弯に骨盤傾斜が合併したり代償性に生じ るとされている。われわれの 2 例に骨盤傾斜が， 3 例 に股関節屈曲拘縮，股関節亚脱臼が合併し，これらが 側弯だけでなく腰椎や胸腰椎前弯の消失，増強にも関 与しているものと考える. 自然経過例の観察より, 早 期発見, 早期治療が必要であったと反省している.

\section{参 考 文 献}

1) Brown, J.C., et al.: Late spinal deformity in qudriplegic children and adolescents. J. Pediat. Orthop., 4 : 456-461, 1984.

2) Campbell, J., Bonett, C.: Spinal cord injury Clin. Orthop., 112: 114-123, 1975.

3) Kilfoyle, R. M., et al. : Spine and pelvic deformity in childhood and adolescent paraplegia. J. Bone and Joint Surg., 47-A : 659-682, 1965.

4) Lancort, J.E., et al. : Palalytic spinal deformity following traumatic spinal-cord injury in children and adolescents. J. Bone and Joint Surg., 63-A : 4753, 1981.

5) Mayfield, J. K., et al. : Spine deformity subsequent to aquired childhood spinal cord injury. J. Bone and Joint Surg., 63-A : 1401-1411, 1981. 